\title{
PANDANGAN ULAMA KABUPATEN PONOROGO TERHADAP PERNIKAHAN DINI: \\ Studi Kasus Pernikahan Dini di Kecamatan Badegan Kabupaten Ponorogo
}

\author{
Dwi Astuti, Furi \\ Institut Agama Islam Sunan Giri (INSURI) Ponorogo \\ Dwiastuti94@gmail.com
}

Abstrak

Early marriage or marriage at a young age is an inner and outer bond that is carried out by a young man or woman who has not yet reached the ideal level to make a marriage, in other words that the marriage is being done before adulthood age. Early marriage still often occurs in Badegan District, Ponorogo. Conducting a field reseach regarding the views of Ponorogo ulama (religious scholars) about early marriage, data collection is done through direct interviews. Then the data is re-examined (editing), systematically arranged in the form of exposure (organizing) and analyzed in accordance with the discussion by using rules, theory and proposition so that it finds valid results. From the data collection, discussion with descriptive analysis method was carried out, namely describing the problem of information that would be used as the object of discussion in order to get a view and legal settlement of the Ponorogo scholars as the end of the research. From this study it can be concluded that (1) Early marriage from the perspective of ulama in Ponorogo according to Fiqh perspective is legal, while in the eyes of positive law in Indonesia, it should be avoided; (2) The basis of the argumentation of scholars in Ponorogo Regency in judging early marriage is naqli and aqli. The naqli basis used in establishing the validity is the proposition of the text of a hadith which narrates that Rasulullah married Aisha at the age of 9, and the basis of the aqli used is benefit to avoid greater harm. As contained in the Marriage Law (UU Pokok Perkawinan) No. 1 of 1974 that limits the age of marriage with the aim of avoiding harm.

Keywords: Early Marriage, Ulama View

Pernikahan di usia muda atau pernikahan dini adalah suatu ikatan lahir batin yang dilakukan oleh seorang pemuda atau pemudi yang belum mencapai taraf yang ideal untuk melakukan suatu pernikahan, dalam artian pernikahan yang dilakukan sebelum dewasa. Pernikahan dini masih sering terjadi di Kecamatan Badegan. Jenis penelitian ini adalah field reseach (penelitia lapangan) mengenai pandangan ulama ponorogo tentang pernikahan dini. Pengumpulan data melalui wawancara langsung dengan ulama. Kemudian data-data tersebut diperiksa ulang (editing), disusun secara sistematis dalam bentuk paparan (organizing) dan dianalisis sesuai dengan pebahasan dengan mengunakan kaidah, teori dan dalil sehingga menemukan hasil yang valid. Dari pengumpulan data tersebut dilakukan pembahasan dengan metode deskriptif analisis. Yaitu menggambarkan masalah tentang informasi yang akan dijadikan sebagai objek pembahasan demi mendapatkan pandangan dan penyelesaian hukum para ulama ponorogo sebagai akhir dari penelitian yang dilakukan. Dari penelitian ini dapat disimpulkan bahwa (1) Hukum pernikahan dini prespektif ulama di Kabupaten Ponorogo menurut kacamata Fiqh adalah sah. Secara kacamata hukum positif yang berlaku di Indonesia pernikahan dini prespektif ulama di Kabupaten Ponorogo yaitu seharusnya pernikahan dini dihindari, (2) Dasar argumentasi ulama di Kabupaten Ponorogo dalam menghukumi pernikahan dini adalah naqli dan aqli. Dasar naqli yang digunakan dalam menetapkan sah tersebut yaitu dalil nash dari sebuah hadith yang meriwayatkan bahwa Rasūlullāh menikahi Aisyah pada usia 9 tahun, dan dasar aqli yang digunakan yaitu kemaslakhatan untuk menghindari kemadharatan yang lebih besar. Seperti yang terdapat dalam Undang-Undang 
Pokok Perkawinan Nomor 1 Tahun 1974 dalam undang-undang tersebut membatasi usia pernikahan dengan tujuan untuk menghindarkan dari kemadharatan.

\section{Kata Kunci : Pernikahan Dini, Pandangan Ulama, Ponorogo}

\section{Pendahuluan}

Agama Islam adalah agama fitrah, dan manusia diciptakan Allah Ta'ala cocok dengan fitrah ini, karena Allah swt. menyuruh manusia menghadapkan diri ke agama fitrah agar tidak terjadi penyelewengan dan penyimpangan. Sehingga manusia berjalan di atas fitrahnya. Pernikahan adalah fitrah kemanusiaan, maka dari itu Islam menganjurkan untuk menikah, karena pernikahan merupakan ghazirah insaniyyah (naluri kemanusiaan). Bila ghazirah ini tidak dipenuhi dengan jalan yang sah yaitu pernikahan, maka ia akan mencari jalan-jalan yang menjerumuskan manusia ke dalam dosa. ${ }^{1}$

Perkawinan merupakan sunnatullah yang umum berlaku pada semua makhluk Allah, baik pada manusia, hewan maupun tumbuh-tumbuhan. Semua yang diciptakan oleh Allah adalah berpasang-pasangan dan berjodoh-jodohan, sebagaimana berlaku pada makhluk yang paling sempurna, yakni manusia. ${ }^{2}$ Perkawinan bukan hanya mempersatukan dua pasangan manusia, yakni laki-laki dan perempuan, melainkan mengikatkan tali perjanjian, yang suci atas nama Allah bahwa kedua mempelai berniat membangun rumah tangga yang sakinah, tentram, dan dipenuhi oleh rasa cinta dan kasih sayang. Untuk menegakkan cita-cita kehidupan keluarga tersebut, perkawinan tidak cukup hanya berdasar pada ajaran-ajaran Allah dalam Al-Qur'an dan As-Sunnah yang bersifat global. Akan tetapi, perkawinan berkaitan pula dengan hukum suatu negara. Perkawinan baru dinyatakan sah jika menurut hukum Allah dan hukum negara telah memenuhi rukun dan syarat-syaratnya.

Untuk mewujudkan keluarga yang bahagia dan kekal, saling menyanyangi dan mengasihi antara satu sama lain dibutuhkan kedewasaan antara calon suami dan calon istri. Kedewasaan dalam bidang fisik-biologis, sosial dan ekonomi, emosi dan tanggug jawab, pernikahan dan nilai-nilai kehidupan serta keyakinan atau agama, akan menyebabkan keluarga yang berbentuk dalam keadaan yang demikian mempunyai saham yang cukup besar dan meyakinkan untuk meraih taraf kebahagiaan dan kesejahteraan hidup dalam keluarganya. ${ }^{3}$ Tujuan pernikahan adalah kedua belah pihak antara laki-laki dan perempuan melangsungkan

\footnotetext{
1 Ahmad Junaidi, Pernikahan Hybrid Studi Tentang Komitmen Pernikahan Wong Nasional Di Desa Patokpicis Kecamatan Wajak Kabupaten Malang (Yogyakarta: Pustaka Pelajar, 2013), 28.

${ }^{2}$ Beni Ahmad Saebani, Perkawinan Dalam Hukum Islam Dan Undang-Undang (Bandung: Pustaka Setia, 2008), 13 .

${ }^{3}$ Hasan Basri, Keluarga Sakinah Tinjauan Psikologis dan Agama (Yogyakarta: Pustaka Pelajar, 2004$), 8$.
} 
pernikahan untuk memperoleh keluarga yang sakīnah, mawaddah dan wārahmah. Salah satu dari tujuan pernikahan atau perkawinan adalah untuk memperoleh keluarga yang sakīnah. Sakinah artinya tenang, dalam hal ini seseorang yang melangsungkan pernikahan berkeinginan memiliki keluarga yang tenang dan tentram. Apabila disalurkan sesuai dengan aturan Islam maka yang tercapai adalah ketenangan dan ketentraman, karena makna lain dari sakinah adalah ketenangan. Ketenangan dan ketentraman ini yang menjadi salah satu dari tujuan pernikahan atau perkawinan. Karena pernikahan adalah sarana efektif untuk menjaga kesucian hati agar terhindar dari perzinahan. Tujuan pernikahan yang selanjutnya adalah untuk memperoleh keluarga yang mawaddah dan wārahmah. Tujuan pernikahan Mawaddah yaitu untuk memiliki keluarga yang di dalamnya terdapat rasa cinta, berkaitan dengan hal-hal yang bersifat jasmaniah. Tujuan pernikahan wāahmah yaitu untuk memperoleh keluarga yang di dalamnya terdapat rasa kasih sayang, yakni yang berkaitan dengan hal-hal yang bersifat kerohanian. Implementasi dari tujuan pernikahan mawaddah wārahmah ini adalah sikap saling menjaga, saling melindungi, saling membantu, saling memahami hak dan kewajiban masing-masing. Dengan demikian seharusnya dalam hubungan suami istri, satu sama lainnya harus saling menutupi kekurangan pasangannya dan saling membantu untuk mempersembahkan yang terbaik.

Dalam pernikahan usia dewasa sesorang pada hakekatnya mengandung unsur yang berkaitan dengan dapat atau tidaknya sesorang mempertanggungjawabkan atas perbuatan hukum yang telah dilakukannya, yang menggambarkan kecakapan seseorang untuk bertindak dalam lingkup hukum perdata. Di pedesaan, pernikahan usia muda atau lebih sering disebut sebagai pernikahan dini lumrah dilakukan. Pernikahan dini sangatlah rawan dalam mengarungi bahtera rumah tangga, sebab tingkat emosional yang terlalu tinggi dalam masa-masa muda dapat memicu pecahnya sebuah ikatan perkawinan. Kematangan jiwa dalam wujud umur dan kedewasaan diri merupakan salah satu unsur supaya tujuan pernikahan untuk mewujudkan keluarga yang bahagia dan kekal dapat terlaksana.

Di Kabupaten Ponorogo data menunjukkan peningkatan angka perkawinan di bawah umur dibandingkan dengan tahun sebelumnya. Hal ini berdasarkan tingginya permintaan surat dispensasi perkawinan di bawah umur yang diajukan ke Pengadilan Agama Ponorogo. Berdasarkan data Pengadilan Agama Ponorogo, sepanjang 2007 rata-rata 15 hingga 19 surat dispensasi telah diajukan perbulan. Sebelumnya rata-rata hanya satu hingga tiga surat perbulan. Perkawinan di bawah umur meningkat 75 persen. $^{4}$

\footnotetext{
${ }^{4}$ Yusdani, Menuju Fiqh Keluarga Progresi (Yogyakarta : Kaukaba Dipantara, 2015), 101.
} 
Salah satu praktik pernikahan dini yang masih terjadi adalah di Kecamatan Badegan Kabupaten Ponorogo. Di zaman yang sudah modern seperti ini dengan tingkat pendidikan yang sudah maju pernikahan dini merupakan suatu hal yang dianggap kuno. Ada beberapa faktor terjadinya pernikahan dini di Kecamatan Badegan Kabupaten Ponorogo di antaranya pelaku pernikahan dini memang sudah ingin mengarungi bahtera rumah tangga di usia yang masih belia, ada pula yang menikah karena dipaksa untuk segera menikah oleh keluarga dan ada pula yang melakukan pernikahan dini karena dari pihak perempuan hamil terlebih dahulu oleh karena itu dari pihak-pihak yang melakukan pernikahan dini juga disertai dispensasi nikah dari Pengadilan Agama Ponorogo. Kenyataan di lapangan menunjukkan bukannya melahirkan kemaslahatan keluarga dan rumah tangga, perkawinan di bawah umur justru banyak berujung pada perceraian. Dampak lain yang lebih luas seperti meningkatnya angka kematian ibu saat hamil atau melahirkan lantaran usia yang masih belia. Dari sudut pandang kedokteran, perkawinan di bawah umur mempunyai dampak negatif bagi ibu dan anak. Menurut psikolog, ditinjau dari sisi sosial, perkawinan di bawah umur dapat mengurangi harmonisasi keluarga.

Ponorogo merupakan kota yang sering disebut sebagai kota santri hal ini dibuktikan dengan adanya 58 lebih pondok pesantren yang ada di kota ini. Dengan fenomena pernikahan dini yang masih terjadi di kabupaten Ponorogo khusunya pada Kecamatan Badegan maka mendorong pada penelitian ini untuk menelaah tentang pandangan ulama terhadap pernikahan dini. Peran ulama di tengah-tengah masyarakat sangatlah penting dan jarang sekali bisa tergantikan oleh generasi setelahnya. Sebab, ulama bukanlah gelar formal ataupun julukan bagi seseorang. Ulama menjadi rujukan dalam masyarakat. Maka, sebagai rujukan dan menimba ilmu sekaligus guru yang bertugas membina umat agar selalu berjalan di atas tuntunan Allah dan Rasul-Nya. Tidak hanya di bidang keilmuan belaka, ulama juga menjadi garda terdepan dalam melakukan aktivitas dakwah. Ulama disebut juga sebagai pembimbing, pembina dan penjaga umat agar selalu berjalan di jalan yang lurus dan benar. Selain itu ulama juga berperan untuk menjaga mereka dari tindak kejahatan, pembodohan dan penyesatan dan segala tindakan asusila di lingkungan masyarakat. Sehingga paradigma ulama dalam kehidupan bermasyarakat sangatlah dibutuhkan.

Dalam Hukum Islam syarat melakukan penikahan adalah ketika calon mempelai lakilaki dan calon mempelai perempuan sudah baligh, dan telah diatur dalam Undang-Undang Pokok Perkawinan Nomor 1 Tahun 1974 pada Pasal 7 ayat (1) menyebutkan bahwa "Perkawinan hanya diizinkan jika pihak pria sudah mencapai umur 19 (sembilan belas) tahun dan pihak wanita sudah mencapai umur 16 (enam belas) tahun”. 
Terlepas dari berbagai ketentuan baik itu dalam fiqh maupun dalam peraturan perundang-undangan yang sifatnya baku dalam mengatur ketentuan pernikahan maka penulis tertarik untuk meneliti mengenai pendapat para ulama yang berada di Kabupaten Ponorogo terkait dengan pernikahan dini. Dalam penelitian ini peneliti akan menelaah beberapa pendapat pribadi dari ulama tersebut menegenai fenomena pernikahan dini, yang akan penulis korelasikan dengan ketetuam dalam hukum Islam maupun peraturan dalam perundangundangan.

\section{Metode}

Jenis penelitian ini adalah field reseach (penelitia lapangan) mengenai pandangan ulama ponorogo tentang pernikahan dini. Pengumpulan data melalui wawancara langsung dengan ulama. Kemudian data-data tersebut diperiksa ulang (editing), disusun secara sistematis dalam bentuk paparan (organizing) dan dianalisis sesuai dengan pebahasan dengan mengunakan kaidah, teori dan dalil sehingga menemukan hasil yang valid. Dari pengumpulan data tersebut dilakukan pembahasan dengan metode deskriptif analisis. Yaitu menggambarkan masalah tentang informasi yang akan dijadikan sebagai objek pembahasan demi mendapatkan pandangan dan penyelesaian hukum para ulama Ponorogo sebagai akhir dari penelitian yang dilakukan.

\section{Pembahasan}

\section{A. Pengertian Pernikahan}

Dalam bahasa Indonesia, perkawinan berasal dari kata "kawin" yang menurut bahasa artinya membentuk keluarga dengan lawan jenis; melakukan hubungan kelamin atau bersetubuh. Perkawinan disebut juga "pernikahan", berasal dari kata nikāh (نكاح) yang menurut bahasa artinya mengumpulkan, saling memasukkan, dan digunakan untuk arti bersetubuh (wathī). Kata "nikāh" sendiri sering dipergunakan untuk arti persetubuhan (coitus), juga untuk arti akad nikah. ${ }^{5}$ Menurut istilah hukum Islam, terdapat beberapa definisi, di antaranya adalah:

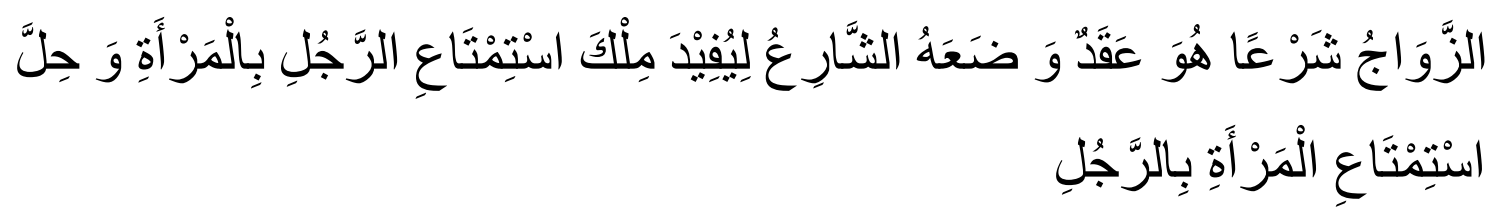

\footnotetext{
${ }^{5}$ Abd. Rahman Ghazaly, M. A, Fiqh Munakahat (Jakarta Timur: PRENADA MEDIA, 2003), 9.
} 
Perkawinan menurut syara' yaitu akad yang ditetapkan syara' untuk membolehkan bersenang-senang anatar laki-laki dengan perempuan dan menghalalkan bersenangsenangnya perempuan dengan laki-laki. ${ }^{6}$

Abu Yahya Zakariya Al-Anshary mendefinisikan:

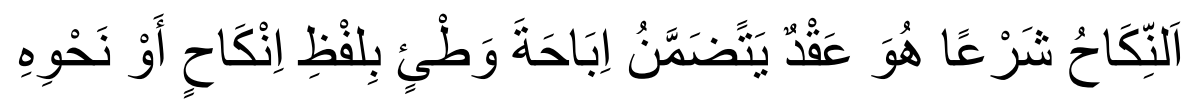

Nikah menurut istilah syara' ialah akad yang mengandung ketentuan hukum kebolehan hubungan seksual dengan lafaz nikah atau dengan kata-kata yang semakna dengannya. ${ }^{7}$

Dalam kaitan ini, Muhammad Abu Ishrah memberikan definisi yang lebih luas, yang juga dikutip oleh Zakiyah Darajat:

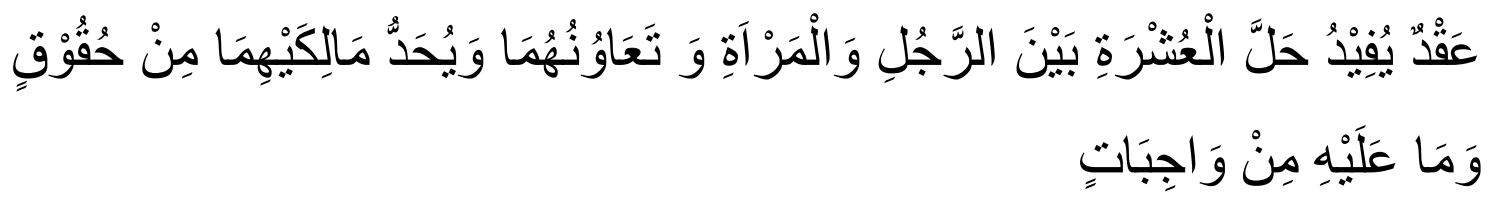

Akad yang memberikan faedah hukum kebolehan mengadakan hubungan keluarga (suami istri) antara pria dan wanita dan mengadakan tolong menolong dan memberi batas hak bagi pemiliknya serta pemenuhan kewajiban bagi masing-masing. ${ }^{8}$

Perkawinan merupakan suatu cara yang dipilih Allah sebagai jalan bagi manusia untuk beranak, berkembangbiak dan menjaga kelestarian hidupnya, setelah masingmasing pasangan siap melakukan perannya yang positif dalam mewujudkan tujuan perkawinan. Tuhan tidak mau menjadikan manusia seperti makhluk lainnya, yang hidup bebas mengikuti nalurinya, dan berhubungan antara jantan dan betinanya secara anarki tanpa suatu aturan. Akan tetapi demi menjaga kehormatan dan martabat, Allah membuat hukum sesuai dengan martabatnya. ${ }^{9}$

Nikah adalah akad yang mengandung pembolehan untuk berhubungan seks dengan lafazh "al-Nikāh" atau "at-tazwij”, yang artinya bersetubuh, dengan pengertian menikahi perempuan maka hakikatnya menggauli istri dan kata "munakāhat" diartikan saling menggauli. Pergaulan yang dimaksud bukan hanya berlaku bagi manusia, tetapi berlaku pula untuk semua makhluk Allah. Binatang pun melakukan pernikahan. Untuk memperhalus terminologi yang berlaku untuk binatang digunakan dengan kata “perkawinan”, meskipun istilah tersebut tidak mutlak, karena dalam Undang-Undang

\footnotetext{
6 Ibid.,

${ }^{7}$ Ibid.,

${ }^{8}$ Abd. Rahman Ghazaly, M. A, Fiqh Munakahat, 10.

${ }^{9}$ Ansori, Abdul Ghofur, Hukum Perkawinan Islam (Yogyakarta: UII Press Yogyakarta, 2011), 21.
} 
Nomor 1 Tahun 1974 dan Peraturan Pemerintah Nomor 9 Tahun 1975 serta Kompilasi Hukum Islam, tidak digunakan kata "nikāh" atau "pernikahan" melainkan digunakan kata "perkawinan". Hal itu artinya bahwa makna nikah atau kawin berlaku untuk semua yang merupakan aktivitas persetubuhan. Karena kata "nikāh" adalah bahasa Arab, sedangkan kata "kawin" adalah kata yang berasal dari bahasa Indonesia.

Nikah adalah asas hidup yang paling utama dalam pergaulan atau embrio bangunan masyarakat yang sempurna. Pernikahan itu bukan saja merupakan satu jalan yang amat mulia untuk mengatur kehidupan rumah tangga dan keturunan, tetapi juga dapat dipandang sebagai satu jalan menuju pintu perkenalan antara suatu kaum dan kaum yang lain, dan perkenalan itu akan menjadi jalan interelasi antara satu kaum dengan kaum yang lainnya. Pada hakikatnya, akad nikah adalah pertalian yang teguh dan kuat dalam hidup dan kehidupan manusia, bukan saja antara suami isrti dan keturunannya, melainkan antara dua keluarga. Baiknya pergaulan antara istri dan suaminya, kasih mengasihi, akan berpindah kepada semua keluarga kedua belah pihak, sehingga mereka menjadi integral dalam segala urusan sesamanya dalam menjalankan kebaikan dan mencegah segala kejahatan.

Abdurahman Al-Jaziri mengatakan bahwa perkawinan adalah suatu perjanjian suci antara seorang laki-laki dan seorang perempuan untuk membentuk keluarga bahagia, definisi itu memperjelas pengertian bahwa perkawinan adalah perjanjian. Sebagai perjanjian, ia mengandung pengertian adanya kemauan bebas antara dua pihak yang saling berjanji, berdasarkan prinsip suka sama suka. Jadi, ia jauh sekali dari segala yang diartikan sebagai paksaan. Oleh karena itu, baik pihak laki-laki maupun wanita yang mau mengikat janji dalam perkawinan mempuyai kebebasan penuh untuk menyatakan, apakah mereka bersedia atau tidak untuk melakukan pernikahan. Pengertian tersebut lebih dipertegas oleh KHI Pasal 2 bahwa perkawinan menurut hukum Islam adalah pernikahan, yaitu akad sangat kuat atau atau mìthāqan ghalīzān, untuk mentaati perintah Allah dan melaksanakannya merupakan ibadah. Menurut Fiqh, pernikahan atau perkawinan ialah: "Suatu Ikatan lahir batin antara seorang laki-laki dan sorang perempuan untuk hidup bersama dalam suatu rumah tangga dan untuk berketurunan, yang dilaksanakan menurut ketentuan-ketentuan hukum syari'at Islam. ${ }^{10}$

10 Zahri Hamid, Pokok-Pokok Hukum Perkawinan Islam dan Undang-Undang Perkawinan di Indonesia (Yogyakarta: Bina Cipta, 1987), 1. 
Menurut Undang-Undang Nomor 1 Tahun 1974 Tentang Perkawinan pada bab 1 DASAR PERKAWINAN Pasal 1 dinyatakan bahwa: "Perkawinan adalah ikatan lahir batin antara seorang pria dan seorang wanita sebagai suami istri dengan tujuan membentuk keluarga (rumah tangga) yang bahagia dan kekal berdasarkan Ketuhanan Yang Maha Esa". ${ }^{11}$

\section{Batas Usia Menikah}

a. Batas Usia Menikah menurut Islam

Pada dasarnya, Hukum Islam tidak mengatur secara mutlak tentang batas umur pernikahan. Tidak adanya ketentuan agama tentang batas umur minimal dan maksimal untuk melangsungkan sebuah pernikahan dan dalam Al-Qur'an mengisyaratkan bahwa orang yang akan melangsungkan pernikahan haruslah orang yang siap dan mampu.

Dalam hal ini Al-Qur'an dan Hadis mengakui bahwa kedewasaan sangat penting dalam pernikahan. Usia dewasa dalam fiqh ditentukan dengan tanda-tanda yang bersifat jasmani yaitu tanda-tanda baligh. ${ }^{12}$ Mengingat bahwa pernikahan merupakan akad/perjanjian yang sangat kuat yang menurut setiap orang yang terkait di dalamnya untuk memenuhi hak dan kewajiban masing-masing dengan penuh keadilan, keserasian, keselarasan dan keseimbangan. Pernikahan sebagai salah satu bentuk pembebanan hukum tidak cukup hanya dengan mensyaratkan baligh (cukup umur) saja. Pembebanan hukum ( $t a$ 'lif) didasarkan pada akal (aqil, mumayyiz), baligh (cukup umur) dan pemahaman.

Bila mencapai usia dewasa, tempat terbaik bagi laki-laki dan perempuan adalah rumah tangga. Rumah tangga menjadi surga pertama dan terbaik bagi kita semua. Dalam bahasa Arab rumah disebut maskan atau tempat memperoleh kestabilan, ketenangan, dan ketentraman hidup. Istilah ini mengandung filosofi tujuan berumah tangga yaitu ketenangan, ketentraman, dan kebahagiaan. ${ }^{13}$

b. Batas Usia Menikah menurut Undang-Undang

Di Indonesia penetapan usia perkawinan terdapat dalam Undang-Undang Pokok Perkawinan pada pasal 7 ayat 1 "Perkawinan hanya diizinkan bila pihak pria mencapai

\footnotetext{
${ }^{11}$ Beni Ahmad Saebani, Perkawinan Dalam Hukum Islam dan Undang-Undang (Bandung: Pustaka Setia, 2008), 15.

${ }^{12} \mathrm{http}: / /$ hakamabbas.blogspot.com/2014/02/batas-umur-perkawinan-menurut-hukum.html/m=1. Diakses pada pukul 10:08 WIB, 3-06-2017

${ }^{13}$ Mohammad Monib \& Ahmad Nurcholis, Fiqh Keluaraga Lintas Agama Panduan Multidimensi Mereguk Kebahagiaan Sejati ( Yogyakarta: Kaukaba Dipantara), 4.
} 
umur 19 tahun dan pihak wanita sudah mencapai umur 16 tahun". ${ }^{14}$ Akan tetapi apabila calon mempelai itu belum cukup umur untuk melaksanakan perkawinan, maka dapat mengajukan dispensasi nikah ke Pengadilan Agama setempat sesuai dengan Pasal 7 ayat 2 yang berbunyi "Dalam hal penyimpangan terhadap Pasal 7 ayat 1 dapat meminta dispensasi kepada Pengadilan atau pejabat lainnya yang ditunjuk oleh kedua orang tua pihak pria maupun pihak wanita". Tidak ada ketentuan yang mengatur tentang "yang belum dewasa dan dewasa" dalam Undang-Undang Nomor 1 Tahun 1974 tentang perkawinan ini dan tidak ada larangan menikah di bawah umur secara eksplisit. Meskipun demikian, penyimpangan terhadap batas usia tersebut dapat terjadi jika ada dispensasi nikah. Dalam hal ini permohonan dispensasi nikah ini diajukan oleh orang tua pemohon yang anaknya masih di bawah batas usia nikah, baik dari orang tua pihak pria maupun orang tua dari pihak wanita kepada ketua Pengadilan Agama di wilayah setempat. Setelah memeriksa dalam persidangan, dan berkeyakinan terdapat hal-hal yang memungkinkan untuk diberikan dispensasi, maka Pengadilan Agama memberikan dispensasi nikah dengan suatu penetapan. Kemudian salinan penetapan itu dibuat dan diberikan kepada pemohon sebagai syarat untuk melangsungkan pernikahan.

Pada Pasal 15 ayat 1 Kompilasi Hukum Islam menyatakan bahwa "Untuk kemaslahatan keluarga dan rumah tangga, perkawinan hanya boleh dilakukan calon mempelai yang telah mencapai umur yang ditetapkan dalam Pasal 7 Undang-Undang Nomor 1 Tahun 1974 yakni calon suami sekurang-kurangnya berumur 19 tahun dan calon istri sekurang-kurangnya berumur 16 tahun”. Menurut ketentuan dalam Kompilasi Hukum Islam di pasal 15, secara jelas bahwa KHI telah membatasi umur calon mempelai (calon suami dan istri) sesuai dengan Undang-undang yang berbeda di atasnya yaitu UU No.1 Tahun 1974 Pasal 7 ayat $1 .^{15}$

\section{Hak dan Kewajiban Suami Istri}

Yang dimaksud hak adalah suatu yang merupakan milik atau dapat dimiliki oleh suami atau istri yang diperolehnya dari hasil perkawinannya. Adapun yang dimaksud dengan kewajiban ialah hal-hal yang wajib dilakukan untuk diadakan oleh seorang suami istri untuk memenuhi hak dari pihak lain. Apabila hak dan kewajiban masing-masing suami dan isteri terpenuhi, maka dambaan suami istri dalam bahtera rumah tangga

\footnotetext{
${ }^{14}$ Undang-Undang Pokok Perkawinan, Pasal 7 Ayat 1 (Jakarta : Sinar Grafika, 2006), 4.

${ }^{15}$ Miftahul Huda, Studi Kawasan Hukum Perdata Islam (Ponorogo: STAIN Ponorogo Press, 2014), 114.
} 
terwujud, didasari rasa cinta dan kasih. Dengan demikian, tujuan hidup berkeluarga akan terwujud sesuai dengan tuntunan agama yaitu sakinah, mawaddah dan rahmah. ${ }^{16}$

Mengenai hak dan kewajiaban suami istri dalam Undang-Undang Pokok Perkawinan Nomor 1 Tahun 1974 diatur dalam Bab VI Pasal 30 samapi Pasal 34. Sementara dalam Kompilasi Hukum Islam diatur dalam Bab XII Pasal 77 sampai Pasal 88. Pasal 31 Undang-Undang Nomor 1 Tahun 1974 berbunyi:

a. Hak dan kedudukan istri adalah seimbang dengan hak dan kedudukan suami dalam kehidupan rumah tangga dan pergaulan hidup dalam masyarakat.

b. Masing-masing pihak berhak untuk melakukan perbuatan hukum.

c. Suami adalah kepala keluarga dan istri adalah ibu rumah tangga. ${ }^{17}$

Ketentuan Pasal 31 tersebut, dalam Kompilasi Hukum Islam diatur dalam bagian kedua tentang kedudukan suami istri Pasal 79. Selanjutnya Pasal 32 UndangUndang Nomor 1 Tahun 1974 berbunyi:

a. Suami istri harus mempunyai tempat kediaman yang tetap.

b. Rumah tempat kediaman yang dimaksud dalam ayat 1 pasal ini ditentukan oleh suami istri bersama. ${ }^{18}$

Hak-hak dalam pernikahan dapat dibagi menjadi tiga, yaitu hak bersama, hak istri yang menjadi kewajiban suami, dan hak suami yang menjadi kewajiban istri. ${ }^{19}$ Palam Pasal 32 tersebut dalam Kompilasi Hukum Islam dituangkan pada Pasal 78. Hakhak bersama antara suami dan istri adalah sebagai berikut:

a. Halal bergaul antara suami dan istri

b. Terjadinya hubungan mahram semanda.

c. Hak saling mendapatkan waris akibat dari ikatan pernikahan yang sah.

d. Anak mempunyai nasab (keturunan) yang baik.

e. Kedua belah pihak wajib bergaul (berperilaku) yang baik.

\section{Pernikahan Dini}

Pernikahan di usia muda atau pernikahan dini adalah suatu ikatan lahir batin yang dilakukan oleh seorang pemuda atau pemudi yang belum menncapai taraf yang ideal untuk melakukan suatu pernikahan, dalam artian pernikahan yang dilakukan sebelum dewasa. Pernikahan dalam usia muda hal ini dapat diartikan menikah dalam usia yang masih muda yaitu sangat diawal waktu tertentu, dalam artian masih dalam kehidupan yang

\footnotetext{
16 Tihami, Sohari sahrani, Fiqh Munakahat, 153.

${ }^{17}$ Undang-Undang Pokok Perkawinan, 11.

18 Ibid.,

19 Ansori, Abdul Ghofur, Hukum Perkawinan Islam (Yogyakarta : UII Press 2011), 100.
} 
belum mapan secara finansial, mungkin bisa dikatakan bahwa lawan dari pernikahan dini adalah pernikahan kadaluarsa atau pernikahan tua.

Pendapat lain, Husein Muhammad, ia mengatakan bahwa pernikahan di usia muda atau belia adalah pernikahan yang terjadi antara laki-laki dan perempuan yang belum mencapai taraf baligh atau mimpi basah, apabila batasan baligh itu ditentukan dalam hitungan tahun, maka pernikahan di usia muda atau belia adalah pernikahan di bawah umur 15 tahun menurut mayoritas ahli fikih, dan di bawah umur 17 atau 18 tahun menurut Abu Hanifah. ${ }^{20}$

Dalam pandangan Hukum Islam dengan Undang-Undang sangat jauh berbeda dalam menentukan batasan umur yang ideal untuk melakukan suatu ikatan pernikahan. Dalam pandangan hukum Islam hanya memberikan batasan kalau sudah mampu, baik mampu dalam melakukan hubungan suami istri dan juga mampu dalam memberikan nafkah untuk anak dan istrinya nanti, di samping itu juga yang lebih diprioritaskan dalam Islam adalah adanya sikap berani, yaitu berani bersikap dewasa dalam menentukan dan menetapkan kapan saat kawin atau menikah. Karena tidak sedikit di antara pemuda yang saat ini menikah pada usia tua karena kurangnya sikap berani yang ada dalam dirinya, padahal dia mampu kalau dilihat dari segi kehidupan baik dari segi harta yang melimpah ruah dan kesehatan jasmaninya. Dengan demikian Islam tidak membatasi umur, akan tetapi walaupun demikian menikah merupakan suatu hal yang harus disegerakan bila dipandang mampu untuk menghadapinya. Berbeda dengan Undang-undang pernikahan negara Indonesia yang menyebutkan bahwa laki-laki berumur 19 tahun dan perempuan berumur 16 tahun sudah diizinkan untuk melangsungkan pernikahan. Oleh karena itu, menikah di usia kurang dari Undang-undang tersebut disebut sebagai pernikahan dini.

Hal-hal yang disebutkan di atas memberi isyarat bahwa perkawinan itu harus dilakukan oleh pasangan yang sudah dewasa. Tentang bagaimana batas dewasa itu dapat berbeda antara laki-laki dan perempuan; dapat pula berbeda karena perbedaan lingkungan budaya dan tingkat kecerdasan suatu komunitas atau disebabkan oleh gaktor lainnya. Untuk menentukan diserahkan kepada pembuat undang-undang di lingkungan masingmasing. Batas usia dewasa untuk calon mempelai sebagaimana dapat dipahami dari ayat Al-Qur'an dan hadits Nabi secara jelas diatur dalam Undang-Undang Pokok Perkawinan Nomor 1 Tahun 1974 pada Pasal 7 dengan sebagai berikut:

a. Perkawinan hanya diizinkan jika pihak pria sudah mencapai umur 19 (sembilan belas) tahun dan pihak wanita sudah mencapai umur 16 (enam belas) tahun.

\footnotetext{
${ }^{20}$ Husein Muhammad, Fiqh Perempuan (Yogyakarta : Lkis, 2001), 68.
} 
b. Dalam hal penyimpangan terhadap ayat (1) pasal ini dapat meminta dispensasi kepada pengadilan atau pejabat yang ditunjuk oleh kedua orang tua pihak pria maupun wanita.

Kompilasi Hukum Islam mempertegas persyaratan yang terdapat dalam Undang-Undang Pokok Perkawinan Nomor 1 Tahun 1974 dengan rumusan sebagai berikut:

Untuk kemaslahatan keluarga dan rumah tangga, perkawinan hanya boleh dilakukan calon mempelai yang telah mencapai umur yang ditetapkan dalam Pasal 7 UndangUndang Nomor 1 Tahun 1974, yakni calon suami sekurang-kurangnya berumur 19 tahun dan calon istri sekurang-kurangnya berumur 16 tahun.

Demikian halnya dengan dispensasi nikah. Bedanya dalam Kompilsi hukum islam disebutkan alasan mengapa dispensasi nikah itu diberikan, yaitu untuk kemaslahatan keluarga dan rumah tangga.

\section{B. Data Pernikahan di Bawah Umur di KUA Kecamatan Badegan dari tahun 2014 - pertengahan tahun 2017.}

Dari pemaparan umum tentang Kecmatan Badegan dengan ini penulis menyajikan beberapa data terkait KUA kecamatan Badegan diataranya ada prorgam kerja, visi dan srtuktur kepegaian, serta data pernikahan dini yang terjadi dari tahun 2014. Pertama terkait Program Kerja KUA Kecamatan Badegan meliputi : Kepenghuluan, Hisab Rukyah, Keluarga Sakinah, Pelayanan Umat Beragama, Produk Halal, dan Sarana Prasarana. Kemudian KUA Kecamatan Badegan mempunyai Visi Misi sebagai berikut:

1. Visi

Mewujudkan kehidupan umat yang beriman, bertaqwa, berakhlak mulia, damai dan sejahtera melalui pola tri kerukunan kehidupan umat beragama.

2. Misi

Memantapkan pelayanan masyarakat dan pengamalan etika moral agama melalui kegiatan administrasi, kegiatan oprasional dan koordinasi lintas sektoral KUA Kecamatan Badegan untuk mewujudkan kerukunan dan kesejahteran umat beragama.

Berikut data pernikahn di bawah umur yang di Kecanatan Badegan yang terjadi pada tahun 2014 sampai dengan bulan Juni tahun 2017:

\begin{tabular}{|c|c|c|c|c|}
\hline Tahun & Bulan & $\begin{array}{c}\text { Jumlah } \\
\text { Pernikahan }\end{array}$ & Identitas & $\begin{array}{c}\text { Keterangan } \\
\text { Desa }\end{array}$ \\
\hline
\end{tabular}




\begin{tabular}{|c|c|c|c|c|}
\hline \multirow{3}{*}{2014} & Februari & 1 & Wanita & Dayakan \\
\cline { 2 - 5 } & Maret & 1 & Wanita & Dayakan \\
\cline { 2 - 5 } & Agustus & 1 & Pria & Dayakan \\
\cline { 2 - 5 } & November & 1 & Wanita & Dayakan \\
\cline { 2 - 5 } & Desember & 2 & $\begin{array}{c}1 \text { Pria } \\
1 \text { Wanita }\end{array}$ & $\begin{array}{c}\text { Kanjungangan } \\
\end{array}$ \\
\hline 2015 & - & - & - & - \\
\hline \multirow{3}{*}{2016} & Maret & 2 & Pria & Karangan \\
\cline { 2 - 5 } & Mei & 1 & Pria & Watubonang \\
\cline { 2 - 5 } & Juli & 2 & 1 Pria & Karangjoho \\
& & & 1 Wanita & Karangjoho \\
\hline 2017 & Mei & 1 & Wanita & Tanjungrejo \\
\hline
\end{tabular}

Dari pemaparan data di atas pernikahan dini dari tahun ke tahun di Kecamatan Badegan memang masih terjadi, dalam pernikahan tersebut tentu saja pihak yang melakukan pernikahan dini membutuhkan dispensi nikah yang ditetapkan oleh Pengadilan Agama Ponorogo. ${ }^{21}$ Karena dengan kondisi seperti ini jelas-jelas pernikahan yang dilaksanakan bukan lagi sebagaimana yang diamanatkan dalam Undang-undang.

\section{Faktor-faktor Penyebab terjadinya Pernikahan Dini}

Adapun faktor-faktor yang yang melatar belakangi terjadinya pernikahan dini di antaranya:

1. Sudah saling mencintai ${ }^{22}$

Hampir kasus terjadinya pernikahan di bawah umur atau lebih sering disebut pernikahan diniyang diajukan di Pengadilan Agama Kabupaten Ponorogoberalasan bahwa telah lama terjalin hubungan cinta kasih yang tidak bisa dipisahkan lagi dan bila tidak segera dilangsungkannya pernikahan dikhawatirkan akan terjadi hal-hal yang tidak diinginkan.

2. Sudah bertunangan ${ }^{23}$

Dengan jalinan kasih yang sudah tidak dapat untuk dipisahkan lagi memberikan dorongan kepada pasangan untuk melakukan pertunangan. Faktor ini termasuk faktor

\footnotetext{
${ }^{21}$ Lihat Transkip Wawancara Nomor 01/W/18-05-2017

${ }^{22}$ Lihat Transkip Wawancara Nomor 01/W/18-05-2017

${ }^{23}$ Ibid.,
} 
yang disebutkan dalam penetapan dari Pengadilan Agama Kabupaten Ponorogo. Tunagan adalah suatu ikatan yang belum dihalalkan menurut Islam, namun dimasyarakat sudah menjadi kebiasaan beriring dengan modernisasi.

3. Kehamilan sebelum menikah ${ }^{24}$

Selain faktor saling mencinta dan tidak dapat saling dipisahkan. Faktor yang dominan terjadinya pernikahan dini adalah pihak perempuan sudah hamil terlebuh dahulu. Dimana bila terjadi kasus yang demikian maka baik dari pihak wali perempuan atau wali laki-laki mengajukan permohonan dispensasi nikah kepada Pengadilan Agama dan alasan inilah yang mempercepat dikabulkannya permintaan dispensasi.

4. Desakan dari Orang Tua ${ }^{25}$

Dari faktor ini tentunya orang tua yang mengendaki untuk segera dilangsungka akad pernikahan dengan alasan kalau tidak segera untuk dinikahkan akan menjadi bahan pembicaraan dari masyarakat sekitar, karena keduanya sudah sering bersama. Dan pernikahan tersebut sebagai sarana untuk menghindari sesuatu yang tidak diinginkan di kemudian hari.

5. Faktor pergaulan ${ }^{26}$

Pergaulan sangat berpengaruh dalam kehidupan sehari-hari terutama pada usia remaja. Dalam lingkup pergaulan anak pada usia remaja sangat rentan terhadap perngaruh dari luar baik dari segi positif maupun negatif. Oleh karena itu jika dalam usia remaja tidak berfikir secara luas dan mempertimbangkan dampak baik dan buruk sebelum melakukan sesuatu dapat dimungkinkan akan mudah terjebak dalam dunia pergaulan bebas.

\section{Pandangan Ulama Kabupaten Ponorogo terhadap Pernikahan Dini}

\section{Hukum Pernikahan Dini Prespektif Ulama di Kabupaten Ponorogo.}

Sebagaimana dalam hukum Islam bahwa Islam tidak menyebutkan batas minimal seseorang dalam melangsungkan pernikahan begitupun hal yang serupa disapaikan oleh beberapa ulama di Kabupaten Ponorogo.

\footnotetext{
${ }^{24}$ Ibid.,

${ }^{25}$ Lihat Transkip Wawancara Nomor 01/W/18-05-2017

${ }^{26}$ Ibid.,
} 
Dalam menanggapi hukum pernikahan dini telah disampaikan oleh Bapak Ahmad Munir selaku mantan ketua Pimpinan Daerah Muhammadiyah Ponorogo menyampaikan bahwa :

"Dalam Islam pada Fiqh perihal pernikahan tidak mengenal umur atau minimal usia dalam pernikahan. Ketika seorang sudah baligh maka boleh-boleh saja melakukan pernikahan". ${ }^{27}$

Berdasarkan kutipan wawancara di atas pernikhan dini memang diperbolehkan dan pernikahan tidak mengenal minimal umur seseorang untuk melangsungkan pernikahan. Sedangkan, batasan yang ditekankan untuk usia melakukan pernikahan adalah baligh. Baligh merupakan anak yang sudah mengalihkannya masa kanak-kanak menuju masa kedewasaan. Secara hukum Islam, seseorang dapat dikatakan baligh apabila seorang tersebut sudah mencapai batasan usia yang telah ditentukan yaitu wanita yang sudah mencapai minimal umur 9 tahun, dan laki-laki sudah mencapai umur 15 tahun. Ciri-ciri baligh untuk seorang laki-laki adalah ketika bermimpi melakukan hubungan layaknya suami istri (Jima). Sedangkan untuk wanita ditandai dengan keluarnya darah menstruasi.

Kedua pendapat dari Bapak Muhsin selaku Syuriah Nahdhatul Ulama Cabang Ponorogo menyatakan bahwa:

"Secara Hukum Pernikahan dini itu Hukumnya sah-sah saja. Dalam melangsungkan Pernikahan Syarat dan Rukun dalam pernikahan tentu saja sangat diperhatikan oleh pihak-pihak yang bersangkutan". ${ }^{28}$

Informasi kedua diperoleh dari Bapak Muhsin dalam ketentuannya menyebutkan pernikahan dini sah, dengan memperhatikan syarat dan rukun dalam pernikahan. Adapaun rukun nikah yaitu mempelai laki-laki, mempelai perempuan, wali, dua orang saksi dan ijāb qabūl. Dengan kentuan syarat calon suami yaitu beragama islam, bukan mahram dari calon istri, tidak terpaksa (atas kemauan sendiri), jelas orangnya dan tidak sedang ihrām. Syarat istri yaitu beragama Islam, tidak ada halangan syarak (tidak bersuami, bukan mahram, tidak sedang dalam iddah), atas kemauannya sendiri, jelas orangnya dan tidak sedang ihrām. Syarat wali yaitu beragama Islam, laki-laki, baligh, waras akalnya, tidak dipaksa, adil dan tidak sedang ihrām. Syarat saksi yaitu beragama

\footnotetext{
${ }^{27}$ Lihat Transkip Wawancara Nomor 02/W/09-06-2017

${ }^{28}$ Lihat Transkip Wawancara Nomor 03/W/09-06-2017
} 
Islam, sekurang-kurangnya dua orang, berakal, baligh, laki-laki dapat mendengar dan melihat, memahami lafadz ijāb qabūl, adil dan tidak sedang ihrām.

Ketiga, pendapat dari Bapak Fuaidzil Hadziq Hamdani selaku pimpinan Pondok Pesantren An Nuur Ponorogo, disampaikan oleh beliau bahwa:

"Dalam Islam tidak ada aturan menikah dalam batasan usia. Dalam Al Qur'an sendiri hanya terdapat batasan usia baligh, bagi laki-laki ditandai dengan mimpi basah, bagi perenpuan ditandai dengan menstruasi. Meskipun dalam Al-Qur'an tidak menyebutkan batasan usia namun dari sisi lain ada perihal yang penting dalam pernikahan yaitu tentang kelayakan.". ${ }^{29}$

Berdasarkan informasi yang diperoleh terkait hukum pernikahan dini yaitu dalam Isam tidak mengenal batasan usia yang digunakan adalah batasan baligh. Namun, ada satu hal yang perlu untuk dipertimbangkan yaitu tentang kelayakan. Sama seperti pendapat sebelumnya dengan batasan baligh. Kelayakan yang dimaksud dalam hal ini adalah pada fase kedewasaan dan perlu dipertimbangkan baik dari sisi biologis maupun psikologis. Sudah layak atau belum seseorang yang akan menikah tersebut.

Pada Madzab Syafi'i menyebutkan asal hukum menikah itu mubah (boleh-boleh saja) dan bukan sunnah karena di kalangan sahabat ada yang tidak menikah dan itu tidak menjadi masalah, kemudian hukum pernikahan bisa menjadi wajib, sunnah, makruh, bahkan sampai pada haram itu dikarena adanya dorongan menuju menikah.

Keempat, disampaiakan oleh Bapak Ansor M Rusydi selaku ketua MUI Kabupaten Ponorogo menyampaikan tentang hukum pernikahan dini bahwa:

"Hukum melangsungkan pernikahan di usia muda atau yang sering disebut pernikahan dini hukumnya menurut Islam sah atau boleh saja selagi syarat dan rukun dalam pernikahan tersebut terpenuhi”,30

Selanjutnya disampaikan oleh Bapak Fatchul Aziz selaku Ketua Pengurus cabang Nahdhatul Ulama Ponorogo, beliau menyampaikan bahwa:

"Hukum Pernikahan usia menurut Islam adalah sah dan diperbolehkan. Dengan ketentuan terpenuhinya syarat dan rukun dalam akad nikah tersebut".31

Disampaikan oleh Bapak Suyitno selaku mantan pengurus ranting Muhammadiyah Mangunsuman bahwa:

\footnotetext{
${ }^{29}$ Lihat Transkip Wawancara Nomor 04/W/09-06-2017

${ }^{30}$ Lihat Transkip Wawancara Nomor 05/W/14-06-2017

${ }^{31}$ Lihat Transkip Wawancara Nomor 06/W/14-06-2017
} 
"Hukum melakukan pernikahan diusia muda boleh dan sah tidak ada masalah asalkan memang dari pasangan tersebut saling menghendaki", 32

Dari pendapat yang dikemukakan oleh Bapak Suyitno pernikahan dini itu diperbolehkan dan hukum melakukan pernikahan adalah sah dan pernikahan tersebut memang saling dikehendaki oleh kedua calon pasangan. Hal ini sesuai dengan ketentuan yang tercantum pada Undang-Undang Pokok Perkawinan Nomor 1 Tahun 1974 pada pasal 6 ayat (1) yang berbunyi "Perkawinan harus didasarkan atas persetujuan kedua calon mempelai”. Sedangkan dalam Kompilasi Hukum Islam terdapat pada Pasal 16 yang berbunyi:

(1) Perkawinan didasarkan atas persetujuan calon mempelai.

(2) Bentuk persetujuan calon mempelai wanita, dapat berupa pernyataan tegas dan nyata dalam tulisan, lisan atau isyarat tapi dapat juga berupa diam dalam arti selama tidak ada penolakan yang tegas

Dari beberapa pandangan ulama di Kabupaten Ponorogo menyatakan bahwa hukum pernikahan dini boleh dengan syarat dan ketentuan yang sesuai dengan aturan yang ada. Ketentuan batas minimal umur dalam melangsungkan pernikahan telah diatur pada Undang-Undang Pokok Perkawinan Nomor 1 Tahun 1974 pada Pasal 7 Ayat (1). Dalam Undang-undang tidak menghendaki pelaksanaan pernikahan dini. Pembatasan umur dalam suatu pernikahan bagi warga negara pada dasarnya bertujuan untuk memberikan aturan atau rambu-rambu dalam melangsungkan pernikahan.

\section{Argumentasi Ulama di Kabupaten Ponorogo terhadap fenomena Pernikahan Dini}

Dalam penyampaian pendapat mengenai hukum pernikahan dini dan menyikapi tentang fenomena pernikahan dini ulama ponorogo pun menggunakan analisis dari berbagai sudut pandang mulai dari perihal yang melatar belakangi terjadinya pernikahan dini. Berikut pendapat ulama Ponorogo terhadap pernikahan dini yang masih sering terjadi. Disampaikan oleh Bapak Ahmad Munir bahwa:

"Seperti halnya yang selama ini kita ketahui bahwa Nabi Muhammad SAW menikahi Aisyah pada saat Aisyah berumur 9 tahun.Namun perlu digarisbawahi bahwa fase kedewasaan dalam pernikahan itu sangatlah penting." ${ }^{33}$

\footnotetext{
${ }^{32}$ Lihat Transkip Wawancara Nomor 07/W/18-06-2017

${ }^{33}$ Lihat Transkip Wawancara Nomor 02/W/09-06-2017
} 
Dalam Fiqh di Indonesia dalam Undang-undang Pokok Perkawinan Tahun 1974 memberikan rambu-rambu tentang batasan minimal umur pernikahan.

Bapak Ahmad Munir menyatakan sepakat dengan Undang-Undang yang berlaku di Indonesia, meskipun di Fiqh tidak ada batasan usia minimal dalam pernikahan karena dalam ketentuan Undang-Undang terdapat kemaslahatan mulai dari populasi penduduk Indonesia dengan itu sangat perlu kesiapan biologis, psikologis dan secara ekonomis.

"Dalam pernikahan dini yang terjadi pada akhir-akhir ini memang karena ada problem, berbagai faktor yang mengharuskan seseorang harus menikah saat itu juga meskipun belum mencukupi dalam ketentuan peraturan yang ada harus menggunakan dispensasi nikah". ${ }^{34}$

Disampaikan oleh bapak Muhsin bahwa pernikahan dini lebih baik jika pernikahan dini itu dihindari. Dengan berbagai macam pertimbagan utamanya sisi biologis dan psikologis calon pengantin.

"Pada dasarnya pernikahan dini tidak masalah, Rasullulah menikahi Aisyah pada umur 9 tahun. Namun, pernikahan yang dilakukan oleh Rasullulah tidak bisa dikatakan sebagai pernikahan dini. Karena tidak ada batasan usia menikah melainkan batasan yang digunakan adalah baligh. Sedangkan pernikahan dini yang terjadi sekarang yang pertama bisa jadi dilatar belakangi karena pihak wanita sudah hamil diluar nikah. Terlepas dari berbagai faktor yang ada yang lebih utama yaitu lebih memikirkan dampak yang akan terjadi setelah pernikahan, mengenai berbagai permasalah yang akan muncul setelah menikah pada usia dini". 35

Seperti kasus yang terjadi melangsungkan pernikahan dini dikarenakan pihak wanita hamil di luar nikah, kasus demikian terjadi karena kecerobohan pihak keluarga, pendidikan keluarga dan pengawasan keluarga terhadap anak. Apabila pengawasan keluarga tidak ceroboh kejadian-kejadian seperti itu dapat dihindarkan. Yang kedua disampaikan oleh Bapak Muhsin pentingnya peran serta dari tokoh-tokoh masyarakat dalam rangka memberikan pencerahan terhadap masyarakat tentang bahayanya pergaulan remaja.

Selanjutnya pendapat dari Bapak Fuaidzil Hadziq Hamdani, beliau menyampaikan bahwa dalam pernikahan dini berkenaan dengan kenyataan yang terpenting adalah kelayakan.

"Jika dikembalikan pada hadith hukumnya boleh saja, namun yang perlu diingat di usia yang masih belia apakah sudah memenuhi unsur kelayakan dalam menikah

\footnotetext{
${ }^{34}$ Lihat Transkip Wawancara Nomor 02/W/09-06-2017

${ }^{35}$ Lihat Transkip Wawancara Nomor 03/W/09-06-2017
} 
atau belum. Yang dimaksud kelayakan disini meliputi berbagai unsur terutama dari segi psikologis. ${ }^{36}$

Maka mengenai fenomena pernikahan dini dapat dikembalikan pada kesadaran orangtua, karena di Ponorogo banyak anak menikah di usia muda kemudian terjadi banyak perceraian dan berakibat pada generasi selanjutnya. Seharusnya dari berbagai elemen masyarakat lebih peka terhadap lingkugan sekitar dalam membaca keadaan di sekitar.

Berikutnya pendapat dari Bapak Ansor M Rusydi sebaiknya pernikahan dilangsungkan ketika usia sudah matang.

"Dalam pernikahan dini merupakan menikah dalam usia masih belia, untuk hukumnya sendiri sah akan tetapi dalam membina kehidupan rumah tangga akan lebih baik jika pernikahan dilangsungkan pada usia yang sudah matang", 37

Berbeda dari pendapat-pendapat sebelumnya pernikahan dini merupakan suatu fenomena yang terjadi pada masyarakat sekarang. Karena dalam Islam tidak ada istilah pernikahan dini. Istilah pernikahan dini muncul yang dilatar belakangi pernikahan yang dilakukan dibawah umur. Disebut dibawah umur karena terdapat batasan usia dalam melakukan pernikahan. Hal ini sesuai dengan pendapat Bapak Fatchul Aziz.

"Di dalam Islam tidak ada istilah pernikahan dini. Pernikahan dini tidak dikenal dalam agama Islam, pernikahan dini hanyalah sebuah istilah yang belakangan sering mucul karena usia kematangan dari calon pengatin masih tergolong usia muda atau belia. Dalam sumber hukum kedua setalah Al-Qur'an adalah Hadits dimana diriwayatkan bahwa Nabi Muhammad SAW menikah dengan Aisyah pada saat Aisyah berusia 7 tahun". 38

Dalam pernikahan dini perlu adanya unsur kehati-hatian serta pertimbagan yang matang. Melihat fenomena banyak pasangan yang kemudian bercerai seharusnya bisa dijadikan pelajaran agar pernikahan yang dilakukan semata-mata tidak hanya untuk mencari kesenangan namun diniatkan untuk beribadah. Salah satu unsur kehati-hatian itu adalah tidak terburu-buru, menikah diusia matang misalnya. Seperti yang disampaikan oleh Bapak Suyitno bahwa :

"Seharusnya pernikahan diusia muda dapat dihindari, demi kemaslahatan bersama. Karena kehidupan setelah menikah jauh lebih sulit dari yang

\footnotetext{
${ }^{36}$ Lihat Transkip Wawancara Nomor 04/W/09-06-2017

${ }^{37}$ Lihat Transkip Wawancara Nomor 05/W/14-06-2017

38 Lihat Transkip Wawancara Nomor 06/W/14-06-2017
} 
dibayangkan membutuhkan komitmen yang kuat untuk bisa mempertahankan rumah tangga dalam kondisi apapun."39

Walaupun seperti yang disebutkan di atas, bahwa dalam satu sisi bahwa pernikahan dini ada positifnya namun tidak dapat dipungkiri bahwa pernikahan dini juga banyak menimbulkan kemadharatan. Dan pernikahan dini merupakan upaya untuk meminimalisir tindakan-tindakan asusila yang terjadi dalam lingkungan pergaulan bebas remaja. Dalam suatu pernikahan komitmen antara pasangan memang haruslah terjalin dengan kuat. Seperti yang paparakan oleh Bapak Suyitno bahwa kehidupan setelah menikah akan lebih sulit jika diatara suami istri tidak saling melengkapi. Oleh karena itu, pernikahan merupakan suatu hal yang harus dipertimbangan secara matang baik secara jasmani dan rohani.

\section{E. Analisis Argumentasi Ulama di Kabupaten Ponorogo terhadap Fenomena Pernikahan Dini}

Di dalam Islam tidak ada istilah pernikahan dini. Pernikahan dini tidak dikenal dalam agama Islam, pernikahan dini hanyalah sebuah istilah yang belakangan sering mucul karena usia kematangan dari calon pengatin masih tergolong usia muda atau belia.

"Seperti halnya yang selama ini kita ketahui bahwa Nabi Muhammad SAW menikahi Aisyah pada saat Aisyah berumur 9 tahun.Namun perlu digarisbawahi bahwa fase kedewasaan dalam pernikahan itu sangatlah penting." ${ }^{40}$

"Di dalam Islam tidak ada istilah pernikahan dini. Pernikahan dini tidak dikenal dalam agama Islam, pernikahan dini hanyalah sebuah istilah yang belakangan sering mucul karena usia kematangan dari calon pengatin masih tergolong usia muda atau belia. Dalam sumber hukum kedua setalah Al-Qur'an adalah Hadits dimana diriwayatkan bahwa Nabi Muhammad SAW menikah dengan Aisyah pada saat Aisyah berusia 7 tahun". ${ }^{41}$

Meskipun di Fiqh tidak ada batasan usia minimal dalam pernikahan karena dalam ketentuan Undang-Undang terdapat kemaslahatan mulai dari populasi penduduk Indonesia dengan itu sangat perlu kesiapan biologis, psikologis dan secara ekonomis.

Pernikahan memerlukan kematangan emosi dan kesiapan fisik dan mental bagi seseorang untuk menjaga klangsungan pernikahan. Pernikahan tidak dibangun untuk suatu waktu tertentu, melainkan untuk waktu yang lama dan kekal dalam ukuran kehidupan manusiayaitu hingga maut memisahkan kehidupan bersama suami dan istri. Keberhasilan sebuah rumah tangga sangat ditentukan oleh kemampuan pasangan dalam mengelola dan

\footnotetext{
39 Lihat Transkip Wawancara Nomor 07/W/18-06-2017

${ }^{40}$ Lihat Transkip Wawancara Nomor 02/W/09-06-2017

${ }^{41}$ Lihat Transkip Wawancara Nomor 06/W/14-06-2017
} 
membina rumah tangga yang langeng dan harmonis. Demikianlah hakekatnya dalam sebuah pernikahan seutuhnya yaitu memperoleh kebahagiaan sejati dalam hidup dalam ridho Allah SWT.

Pada prinsipnya dalam Undang-Undang Nomor 1 Tahun 1974 Tentang Pokok Perkawinan telah menetapkan batasan umur bagi laki-laki dan perempuan untuk melangsungkan pernikahan. Namun, dalam ketentuan yang berlaku apabila usia belum mencukupi untuk melangsungkan pernikahan maka orang tua dapat mengajukan dispensasi nikah ke Pengadilan Agama setempat agar pernikahan tersebut dapat dilaksanakan.

Sesuai dengan prosedur yang ada biasanya hakim menyarankan kepada pihak yang bersangkutan untuk menunda sampai umurnya mencapai ketentuan yang terdapat dalam undang-undang. Apabila yang bersangkutan tidak berkenan dan tetap melanjutkan keinginannya untuk segera menikah karena situasi mendesak misalnya, pihak perempuan sudah hamil terlebih dahulu atau dikhawatirkan akan terjadi perbuatan zina, maka Pengadilan akan mempertimbangkan hal-hal tersebut untuk mengeluarkan surat penetapan izin dispensasi nikah. Yang selanjutnya surat tersebut digunakan bagi pihak yang bersangkutan untuk melangsungkan pernikahan di Kantor Urusan Agama.

Dengan tidak ditetapkannya usia tertentu pernikahan dalam Fiqh sebenarnya memberikan kebebasan bagi manusia untuk menyesuaikan beberapa aspek yang mendorong untuk menikah seperti halnya mengenai kesiapan, kedewasaan dan kultur kebiasaan yang ada dalam masyarakat yang jelas kematangan jasmani dan rohani kedua belah pihak menjadi prioritas utama dalam Agama.

Dalam hal ini beberapa ulama memberikan argumentasinya terkait dengan fenomena pernikahn dini yang masih terjadi sampai sekarang. Dari beberapa informasi yang diperoleh diantaranya akan dipaparkan sebagai berikut :

"Dalam pernikahan dini yang terjadi pada akhir-akhir ini memang karena ada problem, berbagai faktor yang mengharuskan seseorang harus menikah saat itu juga meskipun belum mencukupi dalam ketentuan peraturan yang ada harus menggunakan dispensasi nikah". ${ }^{42}$

"Pada dasarnya pernikahan dini tidak masalah, Rasullulah menikahi Aisyah pada umur 9 tahun. Namun, pernikahan yang dilakukan oleh Rasullulah tidak bisa dikatakan sebagai pernikahan dini. Karena tidak ada batasan usia menikah melainkan batasan yang digunakan adalah baligh. Sedangkan pernikahan dini yang terjadi sekarang yang pertama bisa jadi dilatar belakangi karena pihak wanita sudah hamil diluar nikah. Terlepas dari berbagai faktor yang ada yang lebih utama yaitu

\footnotetext{
${ }^{42}$ Lihat Transkip Wawancara Nomor 02/W/09-06-2017
} 
lebih memikirkan dampak yang akan terjadi setelah pernikahan, mengenai berbagai permasalah yang akan muncul setelah menikah pada usia dini"” ${ }^{43}$

Berdasarkan informasi yang diperoleh dari di atas pernikahan dini terjadi karena ada masalah yang mengharuskan sesorang untuk menikah, meskipun usianya belum mencukupi. Diantara berbagai faktor yang ada diantaranya kedua belah pihak sudah saling mencintai, sudah bertunangan, kehamilan sebelum menikah dan desakan dari orang tua serta faktor pergaulan.

Pengadilan Agama sendiri dalam mengeluarkan surat penetapan dispensasi untuk menikah tidak sembarangan kecuali dengan alasan yang mendesak.

Namun, faktor yang dirasa sangat darurat sehingga Pengadilan Agama mengeluarkan surat izin dispensasi nikah adalah dari pihak perempuan sudah hamil terlebih dahulu.

Mengenai fenomena pernikahan dini yang sebenarnya dapat diminimalisir terkait dengan dampak yang akan terjadi dikemudian hari mengingat usia anak yang belum matang. Memang pernikahan dini boleh dilaksanakan tetapi dengan meminimalisir terjaadinya pernikahan dini sebagai salah satu tindakan preventif agar tidak terjadi hal-hal yang tidak diinginkan.

"Lebih baik jika pernikahan dini itu dihindari. Dengan berbagai macam pertimbagan utamanya sisi bilogis dan psikologis". ${ }^{4}$

Dikembalikan pada kesadaran orangtua, alasan mengapa di Ponorogo masing sering terjadi pernikahan dini dan kemudian terjadi banyak perceraian dan berakibat juga pada keturunan. Di sinilah peranan dari orang tua menjadi salah satu faktor untuk mencegah terjadinya pernikahan dini.

"Jika dikembalikan pada hadits hukumnya boleh saja, namun yang perlu diingat di usia yang masih belia apakah sudah memenuhi unsur kelayakan dalam menikah atau belum. Yang dimaksud kelayakan disini meliputi berbagai unsur terutama dari segi psikologis". 45

"Dalam pernikahan dini merupakan menikah dalam usia masih belia, untuk hukumnya sendiri sah akan tetapi dalam membina kehidupan rumah tangga akan lebih baik jika pernikahan dilangsungkan pada usia yang sudah matang". ${ }^{46}$

Yang perlu digarisbawahi selain usia yang telah ditetapkan dalam peraturan perundang-undangan adalah usia matang. Usia matang dianggap sebagai usia yang ideal

\footnotetext{
${ }^{43}$ Lihat Transkip Wawancara Nomor 03/W/09-06-2017

${ }^{44}$ Lihat Transkip Wawancara Nomor 03/W/09-06-2017

${ }^{45}$ Lihat Transkip Wawancara Nomor 04/W/09-06-2017

46 Lihat Transkip Wawancara Nomor 05/W/14-06-2017
} 
untuk seseorang melangsungkan pernikahan. Usia matang adalah usia dimana seseorang yang benar-benar sudah siap mental, fisik dan psikis, dewasa dan paham arti sebuah pernikahan yangmana pernikahan merupakan bagian dari ibadah, karena apabila sesorang itu tidak siap dalam pernikahan maka dikhawatirkan akan merusak nilai sakral dari pernikahan tersebut.

Dari pemaparan tersebut dapat ditarik sebuah pernyataan bahwa kesiapan dalam melakukan pernikahan mulai dari kematangan psikologis baik calon mempelai laki-laki maupun calon mempelai perempuan, dalam perihal ini kematangan psikologis yang dimaksud adalah kematangan atau kesiapan ataupun kelayakan secara psikis untuk menghadapi berbagai tantangan yang akan dihadapi kelak ketika membangun rumah tangga. Karena seringkali jika secara psikis kondisi seseorang belum siap hal ini dapat berdampak pada keharmonisan dalam rumah tangga.

Kemudian dari sisi biologis seharusnya juga menjadi salah satu pertimbangan yang penting dalam pernikahan yangmana kesiapan biologis berpengaruh terhadap kesehatan, karena dalam Islam kematangan dalam fisik perlu diperthatikan. Ditinjau dari aspek mampu, mampu yang dimaksud di sini adalah mampu dalam hal membina bahtera rumah tangga dan mampu dalam segi ekonomi karena pernikahan bukan hanya hubungan antara seorang lakilaki dan seorang perempuan melainkan hubungan yang di dalamnya terdapat kasih sayang dan kemantapan untuk menuju keluarga yang sakinah, mawaddah, dan warohhmah. Penuh dengan ketentraman, jiwa yang tenang, penuh cinta, dan kasih sayang.

Terlepas dari berbagai dampak positif maupun negatif dari pernikahan dini akan lebih baiknya jika seseorang menikah pada usia matang. Dari berbagai pertimbangan yang ada ternyata pernikahan di usia dini akan menimbulkan efek yang tidak baik jika memang pihak ang bersangkutan tidak siap menjalani kehidupan setelah pernikahan.

Dari salah satu faktor yaitu pergaulan bebas yang memotivasi seseorang untuk melangsungkan pernikahan dini seharusnya bisa dicegah. Faktor pergaulan yang sangat bebas memicu pergaulan antara laki-laki dan perempuan menjadi tidak terbatas inilah yang menimbulkan kasus hamil diluar nikah. Kasus inilah yang menjadi prosentase tertinggi penyebab terjadinya pernikahan dini.

Faktor lain seperti antara kedua belah pihak saling mencintai, sudah bertunangan dan lain sebagainya yang sifatnya tidak mendesak untuk segera dilangsungkan pernikahan sebaiknya ditunda sampai mencapai usia yang ditentukan atau mencapai usia matang. Hal ini tentunya dengan mempertimbangkan kesiapan biologis dan psikologis. 
"Seharusnya pernikahan di usia muda dapat dihindari, demi kemaslahatan bersama. Karena kehidupan setelah menikah jauh lebih sulit dari yang dibayangkan membutuhkan komitmen yang kuat untuk bisa mempertahankan rumah tangga dalam kondisi apapun." 47

Agar perkawinan tidak berakhir pada suatu perceraian harus dicegah adanya perkawinan antara suami dan istri yang masih di bawah umur. Karena perkawinan itu mempunyai hubungan dengan maslaah kependudukan, maka untuk mengerem laju kelahiran yang tinggi harus dicegah terjadinya perkawinan antara calon suami dan istri yang masih di bawah umur. Batas umur yang lebih rendah bagi seorang wanita untuk kawin mengakibatkan laju kelahiran yang lebih tinggi dibandingkan dengan batas umur yang lebih tinggi. Dengan batasan umur yang telah ditetapkan oleh undang-undang maka tujuan perkawinan dapat terwujud. Untuk itu suami istri perlu saling membantu dan melengkapi agar masing-masing dapat mengembangkan kepribadiannya dan mencapai kesejahteraan spiritual dan material.

Pembatasan umur minimal untuk melakukan perkawinan bagi warga negara prinsipnya dimaksud agar orang yang akan menikah diharapkan sudah memiliki kematangan berfikir, kematangan jiwa, dan kekuatan fisik yang memadai. Sehingga kemungkinan keretakan rumah tangga yang berakhir dengan perceraian dapat dihindari, karena pasangan tersebut dinilai memiliki kesadaran yang lebih dan pemahaman yang lebih matang tentang kehidupan berkeluarga.

Berdasarkan pertimbangan hukum, medis dan sosial, tepatlah jika Undang-Undang menetapkan persyaratan usia yang tujuannya untuk menjaga kesehatan suami, istri dan keturunannya.

\section{Kesimpulan}

Hukum pernikahan dini prespektif ulama di Kabupaten Ponorogo menurut kacamata Fiqh adalah sah. Secara kacamata hukum positif yang berlaku di Indonesia pernikahan dini prespektif ulama di Kabupaten Ponorogo yaitu seharusnya pernikahan dini dihindari.

Dasar argumentasi ulama di Kabupaten Ponorogo dalam menghukumi pernikahan dini adalah naqli dan aqli. Dasar naqli yang digunakan dalam menetapkan sah tersebut yaitu dalil nash dari sebuah hadith yang meriwayatkan bahwa Rasūlullāh menikahi Aisyah pada usia 9 tahun, dan dasar aqli yang digunakan yaitu kemaslakhatan untuk menghindari kemadharatan yang lebih besar. Seperti yang terdapat dalam Undang-Undang Pokok Perkawinan Nomor 1

\footnotetext{
${ }^{47}$ Lihat Transkip Wawancara Nomor 07/W/18-06-2017
} 
Tahun 1974 dalam undang-undang tersebut membatasi usia pernikahan dengan tujuan untuk menghindarkan dari kemadharatan.

\section{DAFTAR PUSTAKA}

Al Qur'an dan Terjemahannya. Bandung : PT Cordoba Internasional Indonesia, 2012.

Ansori, Abdul Ghofur. Hukum Perkawinan Islam. Yogyakarta: UII Press Yogyakarta, 2011. Perkawinan Islam Perspektif Fikih Dan Hukum Positif. Yogyakarta : UII Press, 2011.

Basri, Hasan. Keluarga Sakinah Tinjauan Psikologis dan Agama. Yogyakarta : Pustaka Pelajar, 2004.

Ghazaly, Rahman. Fiqh Munakahat. Jakarta Timur: PRENADA MEDIA, 2003.

Hamid, Zahri. Pokok-Pokok Hukum Perkawinan Islam dan Undang-Undang Perkawinan di Indonesia. Yogyakarta : Bina Cipta, 1987.

Huda, Miftahul. Studi Kawasan hukum Perdata Islam. Ponorogo: STAIN Ponorogo Press, 2014.

Junaidi, Ahmad. Pernikahan Hybrid Studi Tentang Komitmen Pernikahan Wong Nasional Di Desa Patokpicis Kecamatan Wajak Kabupaten Malang. Yogyakarta : Pustaka Pelajar, 2013.

Mohammad Monib \& Ahmad Nurcholis. Fiqh Keluaraga Lintas Agama Panduan Multidimensi Mereguk Kebahagiaan Sejati. Yogyakarta: Kaukaba Dipantara.

Muhammad, Husein. Fiqh Perempuan. Yogyakarta : Lkis, 2001.

Saebani, Beni Ahmad. Perkawinan Dalam Hukum Islam Dan Undang-Undang. Bandung : Pustaka Setia, 2008.

Tihami dan Sohari Sahrani. Fikih MunakahatKajian Fikih Nikah Lengkap. Jakarta : Rajawali Pers, 2010.

Undang-Undang Pokok Perkawinan. Jakarta : Sinar Grafika, 2006.

Yusdani. Menuju Fiqh Keluarga Progresif. Yogyakarta : Kaukaba Dipantara, 2015.

http://badegan.ponorogo.go.id/letak-geografis/ diakses pada 05 Juni 2017.

http://badegan.ponorogo.go.id/profil/visi-misi/ diakses pada 05 Juni 2017.

http://hakamabbas.blogspot.com/2014/02/batas-umur-perkawinan-menurut-hukum.html/m=1.

Diakses pada pukul 10:08 WIB, 3-06-2017.

https:id.m.wikipedia.org/Kabupaten_Ponorogo diakses pada 05 Juni 2017. 